\title{
The Research Status of Chinese and Foreign Ecoliterature Study of the Recent 20 Years
}

\author{
WANG Pei-yu \\ School of Foreign Languages, Renmin University of China, Beijing, P. R. China
}

\begin{abstract}
Based on the core and CSSCI source documents from CNKI and American Web of Science's literature on ecoliterature as data source, this paper carries on CiteSpace visualization mapping analysis of Chinese and foreign ecoliterature study of the recent 20 years. By analyzing the lead author, research institute, high frequency keywords, highly cited literature etc., this paper discovers the core topics, research hotspots and frontiers in recent years and the new forms of ecoliterature, the change of international frontier, the new opportunities of ecoliterature research are found. The paper presents a direct view of the study on ecoliterature both in China and abroad. In the end, this paper offers guiding and expectation to Chinese scholars with regard to future research.
\end{abstract}

Keywords: CiteSpace, visualization analysis, ecological literature research, hot research topic, frontier

\section{Introduction}

Ancient Chinese say "The virtuous find pleasure in hills; the wise find joy in water". The Chinese literati have shown their pursuit and interests in bathing in water and seeking joy and fun between forests and streams since a very ancient time. As modern ecological crisis worsens, the terms including ecological culture and ecoliterature come into people's view. According to Chinese scholars, ecoliterature is "a kind of artistic form brought forth by literature and ecology interdisciplinarily" (Fang \& Chen, 2003), elucidating not only the ecological balance in microcosm but also the relation between human and nature in macrocosm (Fang \& Chen, 2003). It describes not only mountains and rivers, but also the poetic life that people experience in nature. The discussion on ecoliterature is intertwined with the focus on ecology for most time. So what are the contents of ecoliterature research in China and around the globe? Checking out the documents on ecoliterature research in Chinese Standard Full-text Database (CNKI), the paper finds that the researches on ecoliterature are limited to traditional theoretical discussion and individual textual analysis. Moreover, some of the literature reviews are the statements of a school that are not necessarily precise and comprehensive. Breaking away from traditional research methods, this paper unprecedentedly resorts to the advanced scientometrics method of CiteSpace, integrates information technology and scientific statistical methods into literature research, and performs scientific quantitative and qualitative analysis on the documents, status, hotspots and frontiers regarding the researches on ecoliterature of recent 20 years in China and abroad by virtue of "the emerging interdisciplinary research field" (Shiffrin \& Borner, 2004), so as to help readers grasp the general of the primary field and analyze and probe into ecoliterature researches in a precise and profound way. Presenting the above-mentioned contents with accurate and vivid visual figures, this paper provides proposals and outlook for latter researches

WANG Pei-yu, Assistant Professor, School of Foreign Languages, Renmin University of China, Beijing, P. R. China. 
on ecological literature and culture on the basis of research findings, in the hope of the booming an sustainable development of ecoliterature as well as the ecological consciousness of the nation.

\section{Research Method and Data Source}

The tool adopted in this paper is CiteSpace of the newest version, 5.1.R6 SE (32-bit).

CiteSpace is a Java application program developed by Professor Chen Chaomei from Drexel University. It is used for identifying and visualizing the new trend and dynamic conditions in scientific documents and has nowadays become a software for information visualization with enormous influence in the field of information analysis. (Xiao, Chen, \& Li, 2011)

It is the WISE (Webometrics, Informetrics, Scientometrics and Econometrics) Lab from Dalian University of Technology (DUT) that first introduced and applied CiteSpace into domestic researches. Professor Liu Zeyuan from DUT, who has been tracing the progress in mapping knowledge domain, is a pioneer in this emerging interdisciplinary field. In 2005 in The Rise of Mapping Knowledge Domain, Professor Liu and Chen Yue scored a first by translating 'Mapping Knowledge Domains' into '科学知识图谱绘制' and mentioning the beneficial exploration Professor Chen Chaomei carried out into the knowledge visualization of the paradigms, paradoxes, and puzzles in science. (Liu, 2017, p. 61)

Thence, the burgeoning scientometrics method of CiteSpace, distinguished for its profound analysis and exploration of the co-cited data of scientific documents, investigation into the general conditions of a certain field, detection of the developmental trend or movements in the field, as well as presentation of the trend by mapping knowledge domains, has been increasingly employed in more of the disciplinary domains (Chen, 2004). Visualized and precise, the CiteSpace mapping can be used to make dynamic analysis, the common procedures of which include subject terms confirming, data collecting, time slicing, threshold selecting, displaying, visualization detecting, and key points checking (Chen, 2006).

The data source in this research contains the journal articles from Chinese Standard Full-text Database (CNKI) and American Web of Science (WOS) and was last updated on September 10, 2017. Searching on CNKI by the subject, ecoliterature, it confines the target documents to journal and the journal source to core and CSSCI so that the quality of data is promised. As a result, 638 articles are found with the publication year of 1997-2017. As for the search of WOS, the data are confined to Science Citation Index-Expanded (SCIE) for the sake of documents quality, the target documents to English articles and proceedings papers that were published in between 1997 and 2017, and the research orientation to literature or literary theory criticism so as to exclude the articles apparently beyond the research field of ecoliterature. Ecological literature as the search term, merely 36 articles are found in WOS. To expand the research data effectively, this paper conducts more searches by the subjects, ecological literature criticism ( 5 articles found), ecological literature (4 articles found) and ecological criticism (32 articles found). Overall 77 results of foreign related data are obtained. Owing to technical limitations, the research results fail to recognize the articles that do not include the search terms in their titles, abstracts and index terms but in effect study the corresponding fields that the search terms reflect. In light of this fact, this paper is suggested by experts to find the source journals of the existing sample documents first and then search the articles at the interface of ecology and literature in the found journals manually, as there is a great possibility to find more articles on ecoliterature on the journals with an ecoliterature-related article published already. After the expansion, 912 more samples are collected, and the samples amount to 989 in total. 


\section{Comparative Study on the Time, Region and Number of Published Papers on Ecoliterature}

A nation's research ability in a special field is directly reflected by the numbers of published papers. To illustrate this, searching by the subject "ecoliterature", we attain Figure 1, revealing how the numbers of research findings at home and abroad distribute by time (the deep curve represents the number of research findings at home; the light represents that at abroad), and Figure 2, displaying how the numbers of papers published on the international journals of SCIE distribute by region. It can be concluded from Figures 1 and 2 that the number of English papers studying ecoliterature on international SSCI exceeds that on domestic core and CSSCI. Moreover, the number of international papers stays stable and considerable and hit its peak in 2014, whereas the study of ecoliterature in China rose to the peak steadily in 2011. As is shown in Figure 2, America publishes the world's most papers on international journals while China publishes the second most, which proves that Chinese domestic studies play a vital role in the field of ecoliterature research but are still supposed to speed up in its internationalization.

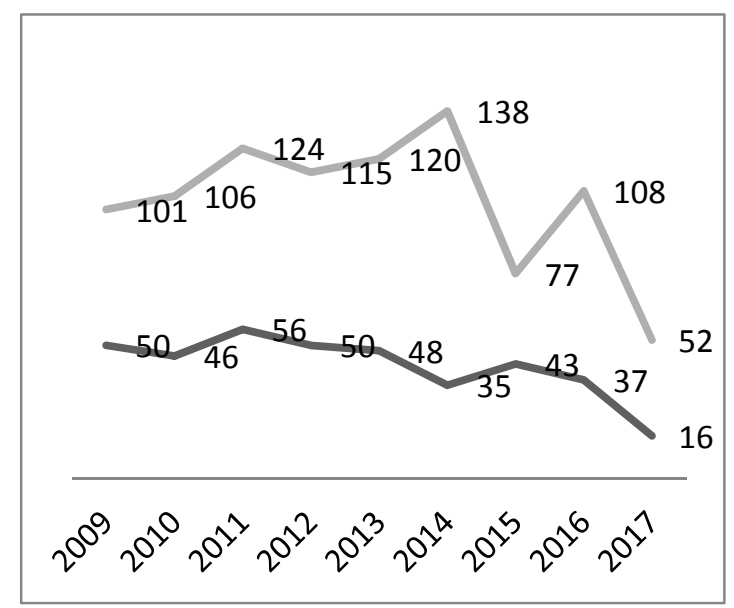

Figure 1. Time distribution of the published papers at home and abroad.

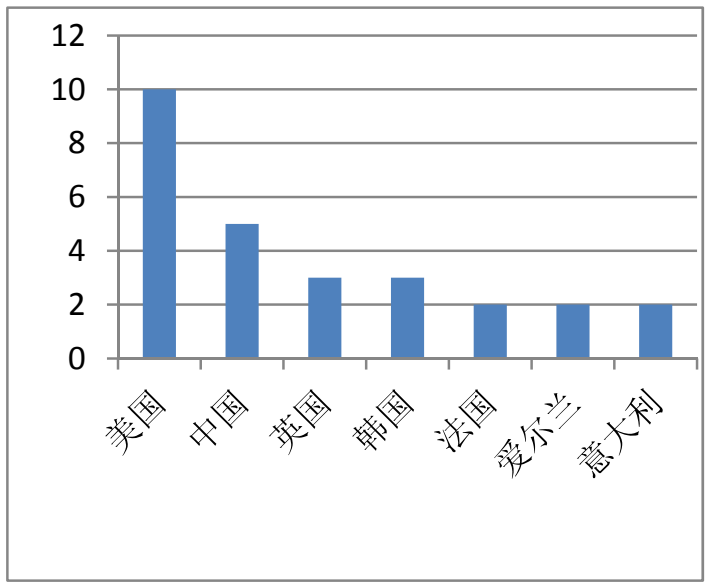

Figure 2. Region distribution of the published papers at home and abroad. 


\section{Visualization Mapping Analysis Based on CiteSpace}

\section{Analysis on the Research Hotspots in China}

For the purpose of probing into the hotspots of researches on ecoliterature in recent 20 years, we import 638 Chinese papers on CNKI into CiteSpace and set the time slicing to be one year, or, namely, perform statistical analysis by the time partition of one year. We set the node type to be term and keyword, select the term sources to be title, abstract, author keywords and keywords plus, and the term type to be noun phases and burst terms. The selection criteria is set as $10 \%$, that means this paper selects the keywords whose frequencies of occurrence are among the top $10 \%$ in each time partition. In the end, we apply CiteSpace to calculate and draw the visualization mapping of Figure 3, in which each circle (or node) represents a keyword and the bigger the node is, the more frequent the keyword occurs. It is widely acknowledged that the core contents of an article are refined by its keywords. If a keyword occurs repeatedly and frequently in the documents of its research field, the research topic it indicates must be the hotspot in this field. The node is constituted by the growth rings with assorted colors. As the growth rings (time partitions) represent the occurrence time of the keywords and their thickness represents the frequency, the larger and thicker the rings are, the more lately and frequently the words occur (Chen, 2012). The cooccurrence relations among the nodes are represented by the lines connecting them; the thicker the lines are, the closer the relations are. Technically limited, this paper fails to present the keywords on those extremely small nodes. As an essential index in discovering and measuring the importance of keywords, betweenness centrality is of great significance in examining the nodes' importance in the network as well. If we compare the node as a bridge connecting two or more individuals or groups, neither or none of them can communicate with each other without the bridge, which hence endows the node with betweenness centrality. Similarly, the betweenness centrality of CiteSpace resembles the keyword erecting a bridge among the studies, without which none of them can interact with each other. Therefore, betweenness centrality reflects a keyword's ability to intermediate in the mapping network; the more it connects, the higher its betweenness centrality is. Those keywords of high betweenness centrality play a strategic part in the whole network, as the higher their betweenness centralities are, the more information flows they control among the keywords (Small, 1986). In the color mapping, they are identified by purple circles. In other words, the purple growth rings represent the research hotspots. As is shown in Figure 3, the biggest node is ecoliterature, with several small nodes distributing inside and around it, which proves the close relation among them and thus forms a cluster, or the gathering of the papers with the same topic and close cooccurrence relation. The mapping knowledge domain of cluster analysis in Figure 4 is obtained through the cluster calculation of CiteSpace. Altogether 71 clusters are detected in Chinese studies on ecoliterature, from which we can see the core fields of its research. On the basis of Figure 3 and Figure 4 respectively, we draw the chart of top 20 keywords with the highest citation frequencies (Table 1) and that of major clusters (Table 2). 


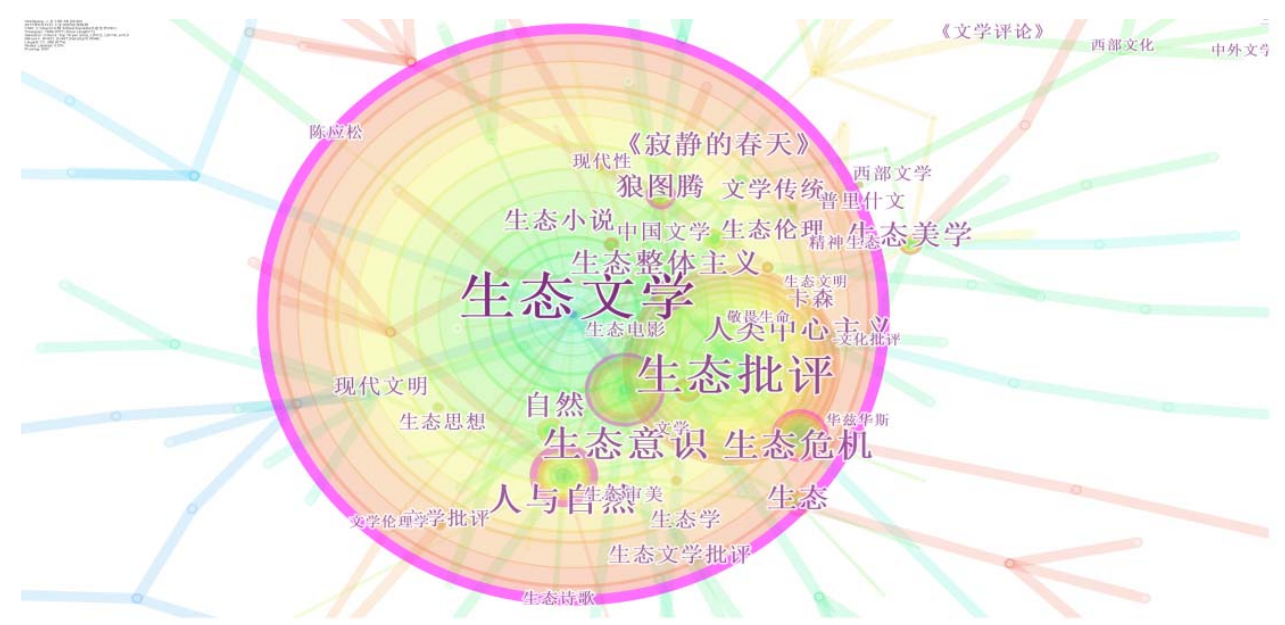

Figure 3. Mapping knowledge domain on keywords of domestic researches in recent 20 years.

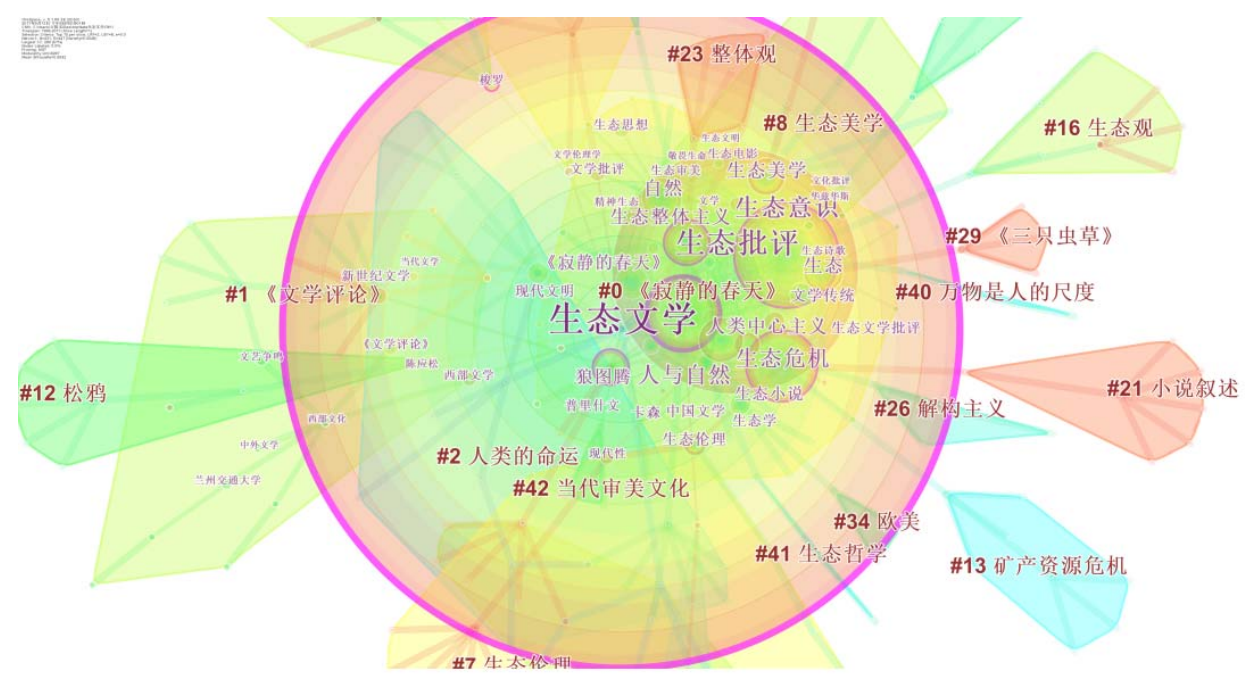

Figure 4. Mapping knowledge domain of cluster analysis on domestic researches in recent 20 years.

Table 1

Top 20 Keywords With the Highest Citation Frequencies

\begin{tabular}{llllll}
\hline No. & Keyword & Citation frequency & No. & Keyword & Citation frequency \\
\hline 1 & Ecoliterature & 208 & 11 & Ecological holism & 15 \\
2 & Ecological criticism & 75 & 12 & Modern civilization & 11 \\
3 & Ecological consciousness & 32 & 13 & Ecological ethic & 11 \\
4 & Human and nature & 24 & 14 & Carson & 10 \\
5 & Ecological crisis & 23 & 15 & Chinese literature & 10 \\
6 & Ecological aesthetics & 17 & 16 & Ecological novel & 10 \\
7 & Ecology & 17 & 17 & Modernity & 9 \\
\hline
\end{tabular}


(table 1 continued)

\begin{tabular}{llllll}
\hline No. & Keyword & Citation frequency & No. & Keyword & Citation frequency \\
\hline 8 & The wolf totem & 16 & 18 & Literary tradition & 9 \\
9 & Anthropocentrism & 15 & 19 & Ecological thought & 9 \\
10 & Silent Spring & 15 & 20 & Ecological philosophy & 9 \\
\hline
\end{tabular}

Table 2

Major Clusters of Domestic Researches in Recent 20 Years

\begin{tabular}{lllll}
\hline Cluster No. & Title & Formation time & Size & Silhouette degree \\
\hline 0 & Ecoliterature criticism & 2007 & 55 & 0.638 \\
1 & Literary review & 2008 & 26 & 0.982 \\
2 & Human destiny & 2001 & 22 & 0.986 \\
3 & Poetic theory & 2008 & 22 & 0.958 \\
4 & Walden & 2008 & 19 & 0.987 \\
5 & Literary writing & 2003 & 18 & 0.936 \\
6 & Foreign literature & 2007 & 15 & 0.97 \\
7 & Ecological ethic & 2009 & 15 & 0.905 \\
8 & Ecological aesthetics & 2007 & 14 & 0.982 \\
9 & Materialism & 2004 & 14 & 0.994 \\
10 & Environmental crisis & 2005 & 10 & 0.996 \\
\hline
\end{tabular}

\section{Analysis on the Scholars, Research Institutes and Journals in China}

Aiming to investigate the overall state of ecoliterature studies in China, this paper tallies up the scholars, research institutes and journals by adopting the document co-citation analysis and author co-citation analysis of CiteSpace. The time slicing is set as one year, and the selection criteria are selected to be top $10 \%$, namely, the top $10 \%$ authors and research institutes that publish the most papers each year. By path finder, this paper obtains the visualization mapping of the authors and research institutes among top $10 \%$. In this mapping, the node represents the author or research institute, and its size represents the number of published papers; the smaller the number is, the more obvious the node is. The lines connecting the nodes embody the relations between authors or research institutes, such as collaboration on a joint paper or the author's employment in the scientific research institute, etc. In the mapping knowledge domain of authors and research institutes, there are many nodes scattering without any connection to each other, from which we can summarize that the studies on ecoliterature in China are mostly undertaken by independent scholars and merely a few of them are accomplished through the scholars' cooperation. As one of the cluster mappings in the group photo of domestic studies, Figure 5 indicates that the topic in this cluster is Chinese contemporary novels. According to the statistics from CiteSpace, the scholars, research institutes and journals with the most papers on ecoliterature published are as what they are in Tables 3, 4 and 5. 


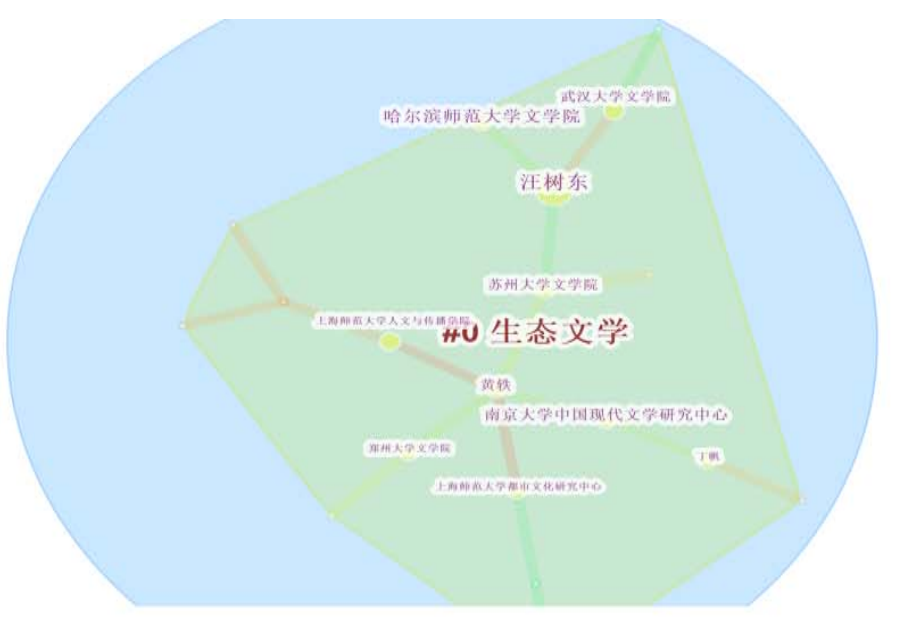

Figure 5. Mapping knowledge domain of cluster analysis on domestic scholars and research institutes.

Table 3

Top 10 Domestic Scholars With the Highest Citation Frequencies

\begin{tabular}{llllll}
\hline No. & Scholar & Citation frequency & No. & Author & Citation frequency \\
\hline 1 & Liu Wenliang & 14 & 6 & Ji Xiuming & 5 \\
2 & Wu Jingming & 10 & 7 & Zhong Yan & 4 \\
3 & Gao Xuguo & 7 & 8 & Huang Yi & 4 \\
4 & Wang Dongshu & 7 & 9 & Wang Nuo & 4 \\
5 & Long Qilin & 5 & 10 & Liu Qinghan & 4 \\
\hline
\end{tabular}

Table 4

Top 10 Domestic Research Institutes With the Highest Citation Frequencies

\begin{tabular}{lll}
\hline No. & Research Institute & Citation frequency \\
\hline 1 & Literature Department, Northeast Normal University & 13 \\
2 & College of the Humanities, Jilin University & 9 \\
3 & Chinese Department, Xiamen University & 7 \\
4 & Center for Research of Literary and Artistic aesthetics, Shandong University & 7 \\
5 & School of Foreign Languages, Nanchang Hangkong University & 5 \\
6 & Department of Chinese Language and Literature, Peking University & 5 \\
7 & School of Foreign Studies, Nanjing University & 5 \\
8 & Center for Research of Chinese Modern Literature, Nanjing University & 4 \\
9 & School of Foreign Languages, Sichuan Normal University & 4 \\
10 & College of Humanities, Guangzhou University & 4 \\
\hline
\end{tabular}

\section{Table 5}

Top 10 Domestic Journals With the Most Ecoliterature Works

\begin{tabular}{lll}
\hline No. & Journal & Number of published papers \\
\hline 1 & Literary Contention & 24 \\
2 & Modern Literary Magazine & 23 \\
3 & Novels Review & 12 \\
4 & Foreign Literature Studies & 12 \\
\hline
\end{tabular}




\begin{tabular}{lll} 
(table 5 continued) & \\
\hline No. & Journal & Number of published papers \\
\hline 5 & Russian Literature & 11 \\
6 & Journal of Northeast Normal University (Social Science) & 11 \\
7 & Contemporary Writers Review & 10 \\
8 & Studies of Ethnic Literature & 10 \\
9 & Academics & 9 \\
10 & Chinese Translators Journal & 5 \\
\hline
\end{tabular}

It is worth mentioning several of the scholars who figure prominently in the study of ecoliterature in China. Liu Wenliang, an eminent scholar whose researches are fruitful and attain the highest citation frequency, is specialized in the macroscopic exposition of ecoliterature. He has exerted significant efforts in the fields of ecological criticism, his major points include highly regarding ecological criticism so that the spiritual ecology of society can be further promoted, and the ecological crisis of nature can be remarkably eased (Liu, 2006). He focused his research on the characteristics of ecological criticism in post-modern destruction and subversion (Liu, 2010), ecological feminist criticism (Liu, 2009), the integration of cultural poetics and ecocriticism (Liu, 2008a), as well as the literature review of ecoliterature studies, the core value and narrative methods of ecoliterature (Liu, 2008b), etc. Moreover, he has paid special attention to the development of and researches on ecological films, for example, the adaptation of the novel, The Wolf Totem (Liu, 2017), the ecological analysis on wolf culture, mini novels and mini films (Liu, 2015), etc. What Liu has studied on ecoliterature corresponds to the research hotspots we have analyzed. By virtue of the scientific statistics, he is ranked to be the scholar with the highest citation frequency, the richest research papers and the strongest influence in the field of ecoliterature studies in China. Besides, his researches on ecological films and television have been guiding domestic hotspots in recent years. Wu Jingming, whose citation frequency is only second to Liu Wenliang's, has carried out researches on a wide range of topics, including the ethics ( $\mathrm{Wu}, 2009 \mathrm{a})$ and social functions $(\mathrm{Wu}$, 2011a) of ecoliterature, lower-class writing and ecoliterature ( $\mathrm{Wu}, 2015)$, the regional novels in Northeastern China and ecoliterature ( $\mathrm{Wu}, 2012)$, ecological fairy tales (Wu, 2010), the novels of the educated youth and ecoliterature ( $\mathrm{Wu}, 2009 \mathrm{~b}$ ), and the development of ecoliterature in recent 20 years $(\mathrm{Wu}, 2009 \mathrm{c})$, etc. In addition, from the perspective of the survival predicaments of human beings, he has made specific textual analysis on the novel, In Memory of the Wolf (Wu, 2011b), and the novels of Fei Ming (Wu, 2014). Wu's studies cover many aspects of ecoliterature researches, from the macrocosmic to the microcosmic, which enlightens subsequent studies some feasible research arenas and methods. Following Wu is Gao Xuguo who enriches the studies on ecoliterature in different lights. He has pointed out that colleges should universalize the education on ecological culture, including that on ecoliterature, as it is of important social functions (Gao, 2012a). He has also highlighted the problems (Gao, 2009a) in domestic ecoliterature criticism, the four models (Gao, 2009b) and the general conditions $(\mathrm{Gao}, 2009 \mathrm{c})$ in ecoliterature studies on a macroscopic level. More of his researches can be seen in the discussion of the ecological turn of modern and contemporary Chinese literature (Gao, 2012b), the significance of ecological writing (Gao, 2012c), Zhe Fu's ecoliterature (Gao, 2013), the ecological crisis in the works of Jia Pingwa (Gao, 2011a), Li Qingsong's ecological reportage (Gao, 2014), and the writing of ecoliterature in the new period (Gao, 2011b), etc. Wang Shudong is another scholar who studies Chinese modern and contemporary novels from the perspective of ecology, which, though, is merely one of his research dimensions. He has deciphered the ecological consciousness in The Wolf Totem (Wang, 2009) and the works of 
Guo Xuebo (Wang, 2006), Zhang Wei (Wang, 2008a), Ye Guangqin (Wang, 2008b), Xu Gang (Wang, 2008c) and Wei An (Wang, 2010), and revealed the ecological outlook in Chinese contemporary novels. Distinctive from the above-mentioned scholars, Wang is more concerned with the specific analysis on the texts. Apart from his textual analysis on Chinese modern and contemporary novels, his reexamination on Western novels that describe adventures at sea from the point of ecocriticism has created substantial impacts as well, for example, his analysis on The Adventures of Robinson Crusoe, Life of Pi, Friday, or, The Other Island (Wang, 2015). Long Qilin is another scholar with major influence in the field of ecoliterature studies, exploring not only Chinese ecoliterature but also its interplay and connection with western ecoliterature. Furthermore, he has looked into the ethics in both western and Chinese ecoliterature (Long, 2015a), the influence and localization of western ecological culture in China, the effects of western ecological culture on Chinese ecoliterature (Long, 2012a), etc. In addition, he has made comparative studies on Chinese and western ecoliterature, to list some of them, Walden and Chinese ecological proses (Long, 2015b), the ecological narrations in D.H. Lawrence's poetry (Long, 2012b), the mythic narrations in western and Chinese poetry (Long, 2015c), and the ecological consciousness in Czesław Miłosz's poetry (Long, 2012c), etc. Long Qilin has dedicated himself to the study of western ecoliterature and the dissemination of the influence of western ecological culture on China. All these scholars, journals and research institutes facilitate the flourishment of ecoliterature studies in China and give full scope to ecoliterature and ecological culture.

\section{Analysis on the Research Hotspots, Authors With High Citation Frequencies and Journals With Most Papers Published at Abroad}

In order to examine the overall state of studies on ecoliterature at abroad, this paper conducts visualization mapping analysis on the English papers obtained in foreign SSCI, and discovers the top 20 keywords with the highest citation frequencies as follows: ecocriticism, ecology, anthropocene (an emerging research orientation proposed by a group of scientists including Crutzen, studying the earth system's changes and adaptations in reaction to human activities and natural environment since 10,000 years ago), postcolonial literature, ecological holism, climate change, nature, posthumanism, postcolonial ecocriticism, romanticism, colonialism, anthropocentrism, environment, eco criticism, conservation, culture, development, ecological consciousness, environmental criticism, and evil in literature. Among the 21 clusters detected, there are 4 major clusters whose topics are ecocriticism, cological holism, culture and environment. As a composite mapping knowledge domain, Figure 6 contains part of the research clusters and keywords on ecocriticism, displaying relevant topics of the clusters of ecocriticism researches. Figure 7 is the mapping knowledge domain of foreign papers on ecoliterature with high citation frequencies. The node represents the author; the higher the citation frequency is, the bigger the node is, and the larger the font is. If two articles are co-cited by another article, there exists a co-cited relation between the two articles (or the two authors). Such a relation is reflected by the line connecting two nodes on the co-cited network of Figure 7. The top 10 authors with the highest citation frequencies are Buell Lawrence, Huggan, Graham, Nixon Rob, Glotfelty C., Garrard Greg, Morton T., Clark T.,

Heise U. K., Wang Nuo and Lu S. As the author with the highest citation frequency, Buell Lawrence, a professor of literature and linguistics at Harvard University, is not only an expert in pre-WWII American literature, but also a pioneer in ecocriticism. Among his most famous works are Ralph Waldo Emerson (2003), Writing for an Endanger World (2001), The Future of Environmental Criticism: Environmental Crisis and Literary Imagination (2005), The American Transcendentalists: Essential Writings (2006), Shades of the 
Planet: American Literature as World Literature (2007). In these works, Professor Lawrence has illuminated the social responsibilities of cultural scholars and the interplay between literary criticism and social criticism. He has pointed out the fact that whether writers or readers, together with common residents and global species, are confronted with challenges. In face of future, literature not only helps human beings reflect, but also influences mediums and culture. Such viewpoints from the circle of environmental criticism are worth being noted and scrutinized. The top 10 international journals with the highest citation frequencies are Ecocriticism Reader, New Literary History, Ecocriticism, Writing for an Endangered World: Literature, Culture and the Environment in the U.S. and Beyond, PMLA-Publications of the Modern Language Association of America, Ecology Without Nature: Rethinking Environmental Aesthetics, Postcolonial Ecocriticism: Literature, Animals, Environment, Interventions-International Journal of Postcolonial Studies, Sense of Place and Sense of Planet: The Environmental Imagination of the Global, Slow Violence and the Environmentalism of the Poor. All these international authors and journals mark a crucial milestone in the studies of ecoliterature and serve as important precedents for us to learn from.

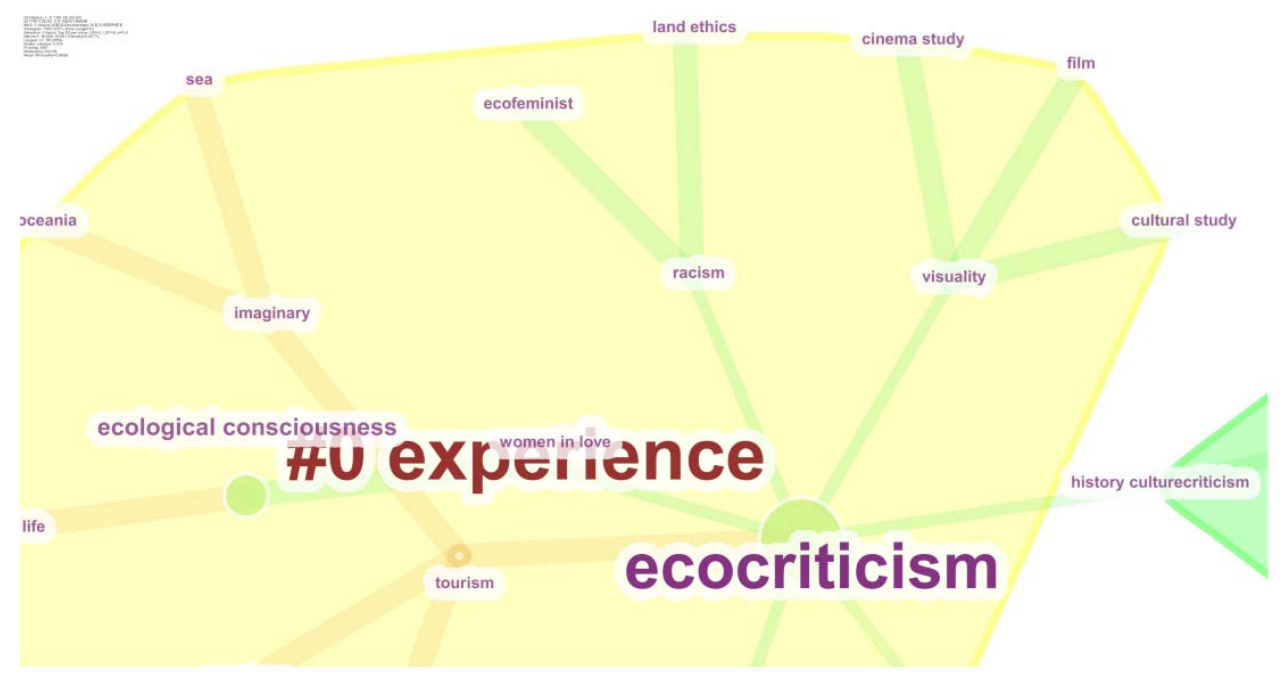

Figure 6. Part of the mapping knowledge domain of cluster analysis on foreign researches. 


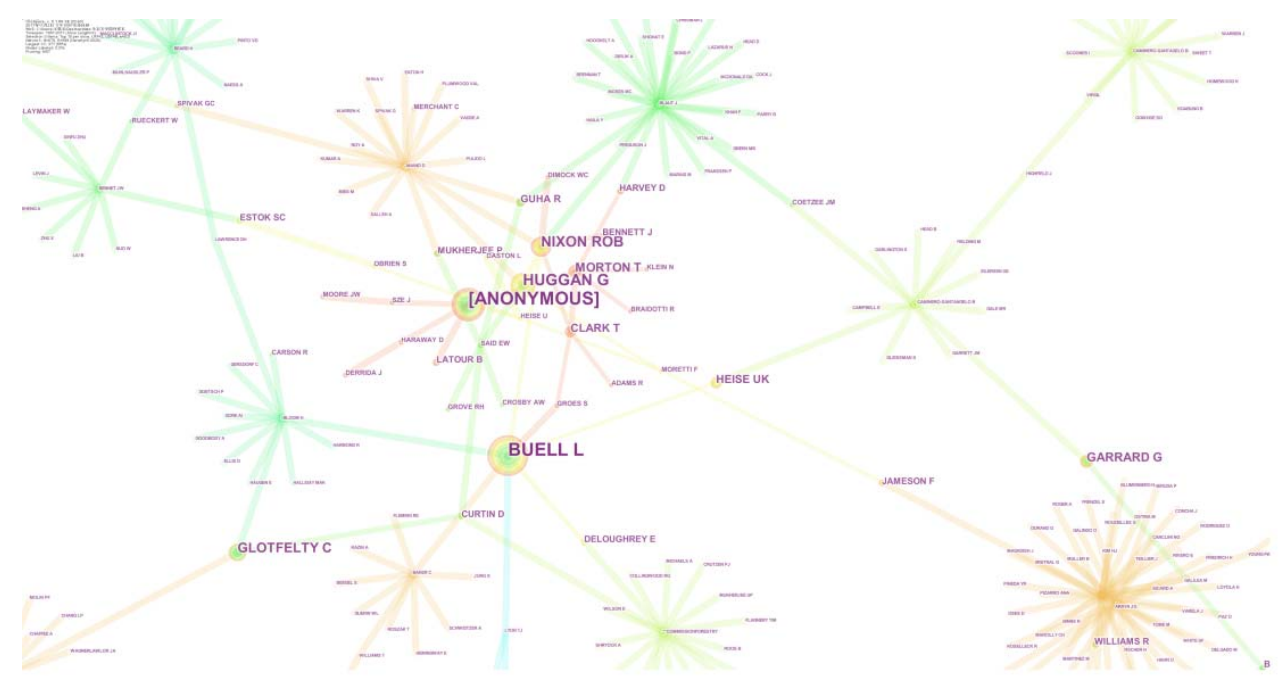

Figure 7. Mapping knowledge domain of international authors with high citation frequencies.

\section{Exploration of Research Frontiers in China and Abroad}

To explore the research frontiers in a certain field, not only its primary knowledge structure and present research situation, but also its global research state and hotspots in recent years are required. The visualization analysis of CiteSpace can be used in the progressive analysis of co-cited networks. We come to the changes of keywords in the research hotspots in China in recent 5 years by CiteSpace. Figure 8 is the mapping knowledge domain of words with high frequencies in domestic research hotspots in recent 5 years. As it shows, these words are: ecoliterature, ecological criticism, ecological consciousness, ecological holism, human and nature, anthropocentrism, ecological aesthetics, ecoliterature criticism, ecological ethic, ecological crisis, ecological film, ecological novel, modernity, nature, spiritual ecology, contemporary literature, ecological connotation, scientific prose, and the wolf totem. Displaying the changes of research emphasis at home in recent 5 years, Figure 9 indicates that new hotspots of ecoliterature studies are found, for instance, ecological film, contemporary novel and ecological aesthetics, etc. 


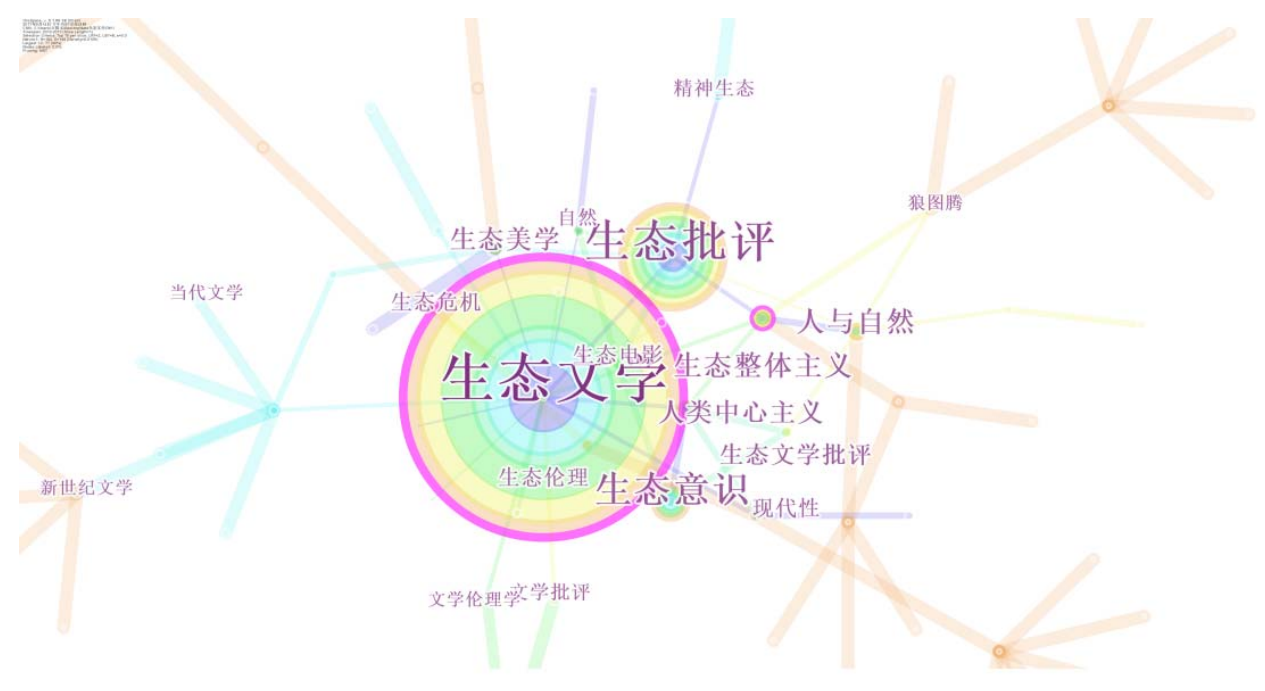

Figure 8. Words with high frequencies in domestic research hotspots in recent 5 years.

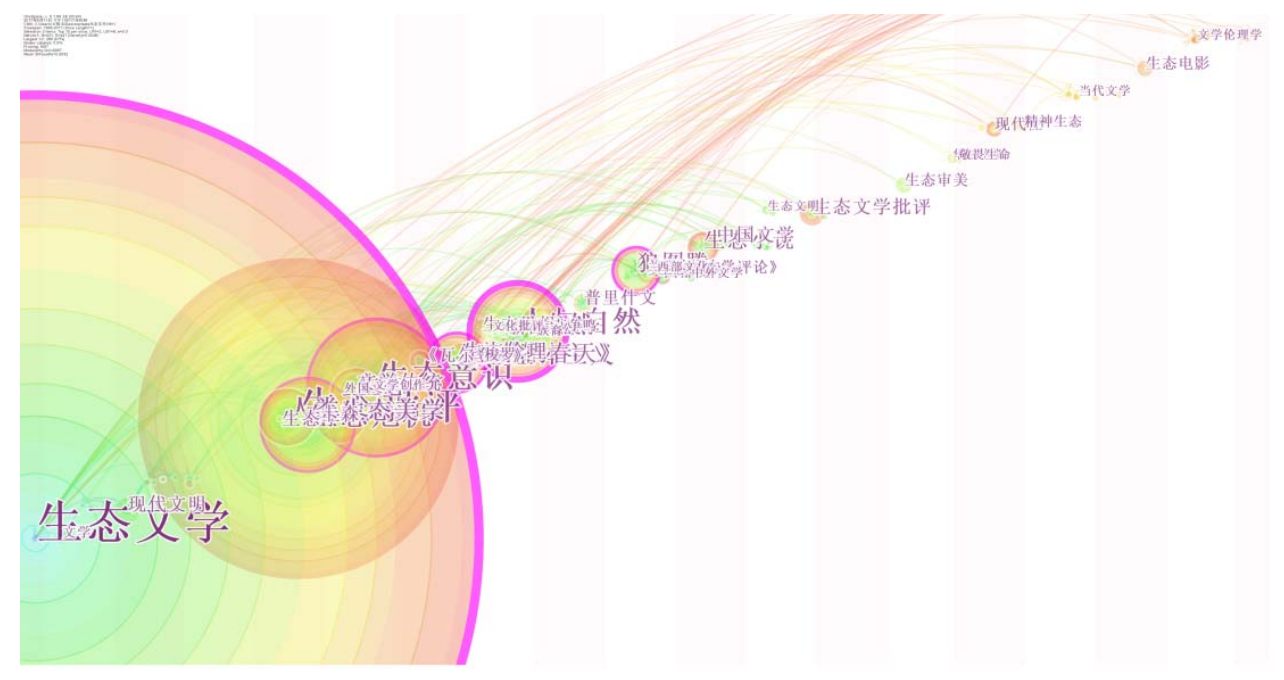

Figure 9. Mapping knowledge domain of changes on domestic research hotspots in recent 5 years.

We also investigate the keywords with high frequencies in the research hotspots at abroad in recent 5 year for the global horizon of this paper. These words are: ecocriticism, anthropocene, postcolonial literature, climate change, post humanism, postcolonial ecocriticism, development, ecology, ecological awareness, environmental criticism, new technology and social media, education, South Africa, genre fiction, environmental violence, and literary criticism. Such conclusion can be made from the changes of research hotspots in China and abroad in recent 5 years that Chinese scholars are still attached to the studies on classic ecoliterature like The Wolf Totem and embark on their researches on a wider range of fresh literary forms from ecological films and their adaptations to scientific proses, mini novels and mini films. The studies on 
ecoliterature have been fruitful for ten years in China, and therefore what the following scholars are supposed to shed more lights on is the valuable topics encompassed in those fresh literary forms. We also note that among the research hotspots at abroad in recent 5 years, the topics brought about by climate change, new technology and social media have aroused intense interests among the scholars. Ecoliterature is an interdisciplinary field of ecology and literature. Nowadays the researches on it have been introduced to more fields. To cite Berman Douglas' study as an example, he has conducted a research on the extensive attention that ecologism has captured in the realm of the humanities and pointed out that the interplay of literature, medias and films has developed ecologism into an authoritative school. His research has sketched the Chinese history of ecological movement and attached foremost importance to the issue of how the literary critics should propel ecologism toward an energetic school (Berman Douglas, 2015). What Douglas discusses has linked media with the impacts of films on ecoliterature. Foreign scholars have also carried out other studies such as on Rachel Carson, a scientist and writer who combines greenism, science and technology with creative writing (Baratta, 2016). By tracing back to the traditional Alaskan myths, Groes Sebastian has expounded how climate change transforms people's cognition in the 21 st century (Groes, 2017). The studies foreign scholars have made provide helpful references for Chinese scholars. Besides, the analysis on the cited papers indicates that Chinese researchers lean more on the reference and citation of domestic documents. Only by equipping domestic scholars with global horizons and their effective referencing and applying of international papers with high citation frequencies can the researches on ecoliterature in China become more internationalized and of greater influence all over the world. In the process of the internationalization, Figure 7 supplies a conducive reference.

\section{Conclusion}

With the assistance of CiteSpace, a tool for visualization analysis in the discipline of informetrics, we are presented with a clear and scientific panorama of the researches on ecoliterature in China and abroad. The steadily and continuously increasing number of published papers reflects both domestic and foreign scholars' enthusiasm in this field. Through the hotspots and frontiers analysis, we grasp the core and frontier topics, the new forms of ecoliterature, including ecological films, mini novels and mini films, coupled with the changes of ecoliterature and our opportunities and challenges generated by climate change, new technology and social media etc. Ecoliterature authors write about nature, while ecoliterature researchers concern nature, the studies on ecoliterature are of immense social significance at the age. The author ardently looks forward to the further development of ecoliterature researches in China. Since this paper performs analysis only on the core and CSSCI documents from CNKI and SSCI documents from WOS, a large volume of other documents is hoped to be further studied. More researches on the relevant fields of ecoliterature, including those documents in English or other foreign languages, are expected.

\section{References}

Berman Douglas, S. (2015). Chinese ecocriticism: A survey of the landscape. Literature Compass, (8), 396-403.

Baratta, C. (2016). "Interdisciplinarity" achieved: A brief look at interdisciplinary environmentalism in the 1960s. Interdisciplinary Literary Studies, (3), 301-324.

Chen, C. M. (2004). Searching for intellectual turning points: progressive knowledge domain visualization. In Proceedings of the National Academy of Sciences, 101(1), 5303-5310.

Chen, C. M. (2006). CiteSpace II: Detecting and visualizing emerging trends and transient patterns in scientific literature. Journal of the American Society for Information Science and Technology, (3), 359-377. 
Chen, C. M. (2012). Predictive effects of structural variation on citation counts. Journal of the American Society for Information Science and Technology, (3), 431-449.

Fang, J., \& Chen, X. (方军, 陈昕). (2003). 论生态文学 [J]. 中南民族学院学报, (2), 141-144.

Groes S. (2017). "I Love Alaska": Posthuman subjectivity and memory on the final frontier of our ecological crisis. Textual Practice, (31), 973-993.

Gao, X. G. (高旭国). (2009a). 生态批评的若干问题[J]. 中国文学研究, (4), 59-62.

Gao, X. G. (高旭国). (2009b). 国内生态文学研究的四种模式[J]. 中州学刊, (6), 231-236.

Gao, X. G. (高旭国). (2009c). 国内生态文学研究述评[J]. 宁夏师范学院学报, (5), 92-102,107.

Gao, X. G. (高旭国). (2011a). 精神生态危机的悲凉写照一重读《废都》 [J]. 中南民族大学学报 (人文社会科学版)，(2), 162-166.

Gao, X. G. (高旭国). (2011b). 新时期生态文学创作论纲[J]. 新疆大学学报 (哲学、人文社会科学版)，(5), 120-125.

Gao, X. G. (高旭国). (2012a). 大学生态文化教育要论[J]. 黑龙江高教研究, (3), 68-70.

Gao, X. G. (高旭国). (2012b). 中国现当代文学的生态性写作转向[J]. 吉首大学学报, (5), 55-61.

Gao, X. G. (高旭国). (2012c). 生态写作的文学史意义[J]. 唐山学院学报, (5), 71-75.

Gao, X. G. (高旭国). (2013). 论哲夫的生态文学创作 $[J]$. 西华大学学报 (哲学社会科学版), (3), 27-32.

Gao, X. G. (高旭国). (2014). 论李青松的生态报告文学[J]. 当代作家评论, (2), 111-116.

Long, Q. L. (龙其林). (2012a). 生态语境下的文化与文学传播一西方生态文化思潮与中国生态文学的发生 [J]. 重庆文理学 院学报 (社会科学版) , (3), 43-48.

Long, Q. L. (龙其林). (2012b). 为溃退的自然见证-D.H.劳伦斯诗歌的生态叙事 [J]. 北方论丛, (4), 53-56.

Long, Q. L. (龙其林). (2012c). 大地乌托邦的记忆者一切米沃什诗歌的生态意识[J]. 徐州师范大学学报 (哲学社会科学版), (2), 44-48.

Long, Q. L. (龙其林). (2015a). 从他者到本位: 中西生态文学伦理的现代转型[J]. 湘潭大学学报 (哲学社会科学版)，(1), 92-96.

Long, Q. L. (龙其林). (2015b). 重寻荒野价值与融入野地情结一论《瓦尔登湖》与张炜生态散文[J]. 青岛科技大学学报 (社 会科学版) , (2), 96-100.

Long, Q. L. (龙其林). (2015c). 从神话复归到文明反思一当代中西生态文学中的神话叙事 [J]. 江苏师范大学学报(哲学社会 科学版), (1), 75-79.

Liu, G. Y. (刘光阳). (2017). CiteSpace国内应用的传播轨迹*——基于 $20006-20015$ 年跨库数据的统计与可视化分析 [J]. 图书情报知识, (2), 61 .

Liu, W. L. (刘文良). (2006). 和谐社会视域中的生态文学[J]. 理论与现代化, (5), 103-107.

Liu, W. L. (刘文良). (2008a). 文化诗学视域中的生态批评[J]. 云南社会科学, (4), 145-148.

Liu, W. L. (刘文良). (2008b). 生态文学的艺术化叙事方式[J]. 河北学刊, (3), 113-115.

Liu, W. L. (刘文良). (2009). “双重视角”与生态女性批评的独特魅力[J].北方论从, (2), 45-48.

Liu, W. L. (刘文良). (2010). 生态批评的后现代特征[J]. 文学评论, (4), 81-86.

Liu, W. L. (刘文良). (2015). 生态微电影的“阐微”之道[J]. 中州学刊, (4), 151-154.

Liu, W. L. (刘文良). (2017). 《狼图腾》小说电影改编的升华与超越[J]. 电影文学, (7), 104-106.

Small, H. (1986). The synthesis of specialty narratives from co-citation clusters. Journal of the American Society for Information Science, 37(3), 97.

Shiffrin, R. M., \& Borner, K. (2004). Mapping knowledge domains. In R. M. Shiffrin and K. Borner (Eds.), Proceedings of the National Academy of Sciences of the United States of America (101 (Suppl 1), p. 5183). National Academies Press.

Wu, J. M. (吴景明). (2009a). 生态文学的伦理文化诉求[J]. 当代文坛, (4), 20-23.

Wu, J. M. (吴景明). (2009b). 知青文学中自然书写的多重意蕴[J]. 广西社会科学, (3), 95-101.

Wu, J. M. (吴景明). (2009c). 从展示危机到参与重建一中国当代生态文学发展简论[J]. 学术界, (6), 256-264.

Wu, J. M. (吴景明). (2010). 用奇幻点燃孩子的生态意识一中国当代生态童话简论 [J]. 东北师大学报 (哲学社会科学版), (5), 124-127.

Wu, J. M. (吴景明). (2011a). 《怀念狼》：人类生存困境的生态思考 [J]. 文艺争鸣, (3), 146-147.

Wu, J. M. (吴景明). (2011b). 从“激情呐喊”到“诗意栖居”一生态文学的社会功用与诗性智慧[J]. 当代文坛, (3), 9-12. 
Wu, J. M. (吴景明). (2012). 与大自然共生共存一新时期东北地域小说生态意识的演进 [J]. 学习与探索, (2), 132-135.

Wu, J. M. (吴景明). (2014). 生态批评视野中的废名小说创作[J]. 中国现代文学研究从刊, (2), 119-124.

$\mathrm{Wu}$, J. M. (吴景明). (2015). 新世纪社会转型与底层写作、生态文学的兴起[J]. 当代文坛, (1), 50-53.

Wang, S. D. (汪树东). (2006). 看护大地: 生态意识与郭雪波小说 [J]. 北方论丛, (3), 34-37.

Wang, S. D. (汪树东). (2008a). 生态意识与张炜文学创作[J]. 南京师范大学文学院学报, (4), 8-13.

Wang, S. D. (汪树东). (2008b). 为动物而哀歌: 生态意识与叶广芩小说[J]. 河南科技大学学报 (社会科学版)，(6), 50-55.

Wang, S. D. (汪树东). (2008c). 守望大地: 生态意识与徐刚的生态文学[J]. 山东理工大学学报 (社会科学版), (2), 15-19.

Wang, S. D. (汪树东). (2009). 论《狼图腾》的生态意识[J]. 前沿, (5), 88-92.

Wang, S. D. (汪树东). (2010). 生态意识与苇岸散文[J]. 南京师范大学文学院学报, (2), 39-44.

Wang, S. D. (汪树东). (2015). 从生态批评视角重审西方漂流小说[J]. 西南大学学报 (社会科学版), (1), 144-152.

Xiao, M., Chen, J. Y., \& Li, G. J. (肖明, 陈嘉勇, 李国俊). (2011). 基于CiteSpace研究科学知识图谱的可视化分析[J]. 图书 情报工作, (6), 91 . 